\title{
Review of Reports by J. W. Gofman on Inhaled Plutonium
}

by

w. J. Bair

October 10, 1975

Prepared for the Energy Research and Development Administration under Contract E(45-1):1830 
This report was prepared as an account of work sponsored by the United States Government. Neither the United States nor the Energy Research and Development Administration, nor any of their employees, nor any of their contractors, subcontractors, or their employees, makes any warranty, express or implied, or assumes any legal liability or responsibility for the accuracy, completeness or usefulness of any imiormation, apparatus, product or process disclosed, or represents that its use would not infringe privately awned rights.

\title{
PACIFIC NORTHWEST LABORATORY operated by \\ BATTELLE \\ for the
}

ENERGY RESEARCH AND DEVELOPMENT ADMINISTRATION

Under Contract E(45-1)-1830

\author{
Printed in the United States of America \\ Available from \\ National Technical Information service \\ U.S. Department of Commerce \\ 5285 Port Rovai Road \\ Springtield. Virginia 22151 \\ Price: Printed Copy \$4.50; Micratiche 52.25
}


BNWL-2067

UC-41

33679000624868

REVIEW OF REPORTS BY J. W. GOFMAN ON INHALED PLUTONIUM

by

W. J. Bair

October 10, 1975

Battelle

Pacific Northwest Laboratories

Richland, Washington 99352 


\section{FOREWORD}

This report was prepared as part of a response by the Division of Biomedical and Environmental Research, Energy Research and Development Administration, to an inquiry from the U. S. Congress Joint Committee on Atomic Energy (JCAE) for a thorough scientific review of two papers by Dr. J. W. Gofman. Gofman's articles were written for the Committee for Nuclear Responsibility, Dublin, CA, and have been entered into the Congressional Record in summary form (July 31, 1975). This report and four others by staff members of ERDA laboratories have been provided to the JCAE for use in their consideration of Gofman's allegations concerning the potential health effects of inhaled plutonium. 


\section{CONTENTS}

FOREWORD $\cdot$ •

INTRODUCTION

BASES OF GOFMAN'S ARGUMENTS . . . . . . . . . . . 1

The Risk-Per-Unit-Dose Concept . . . . . . . . . 2

The Multiplier Effect of Alpha Radiation . . . . . . . 4

Increased Cancer Risk to Smokers . . . . . . . . . 5

OTHER ERRORS IN GOFMAN'S LOGIC . . . . . . . . . . . 8

CONCLUSIONS . . . . . . . . . . . . . . . . 9

ACKNOWLEDGMENTS . . . . . . . . . . . . . . 10

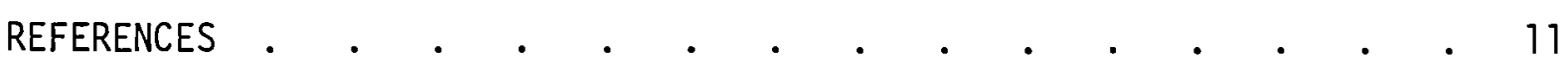


REVIEW OF REPORTS BY J. W. GOFMAN ON INHALED PLUTONIUM

W. J. Bair

\section{INTRODUCTION}

Two recent widely circulated reports on the subject of inhaled plutonium have provoked concern among the press ${ }^{(1)}$ and in Congress. (2) These reports, The Cancer Hazard from Inhaled Plutonium, CNR Report 1975-1R, May 14, 1975, and Estimated Production of Human Lung Cancers by Plutonium from Worldwide Fallout, CNR Report 1975-2, July 10, 1975, were written by John W. Gofman and issued by the Committee for Nuclear Responsibility, P.0. Box 2329, Dublin, California 94566.

Gofman's reports do not present an objective analysis of the hazard of inhaled plutonium; his arguments, in fact, contradict many conclusions drawn in the scientific literature and supported by experimental data. Because the reports are skillfully written, however, they could easily mislead readers who are not well versed in this area. The purpose of this review, therefore, is to examine Gofman's reports in the light of recent research studies and to identify errors of fact and logic in his arguments.

\section{BASES OF GOFMAN'S ARGUMENTS}

In the first report, "The Cancer Hazard from Inhaled Plutonium," Gofman develops a "lung cancer dose" concept for inhaled plutonium. He claims that the potential for lung cancer from inhaled plutonium has been grossly underestimated because unrealistic models have been used for clearance of plutonium from the respiratory tract and because the bronchi have not been recognized as the site of most human lung cancers; that the lung cancer hazard from plutonium is much higher in cigarette smokers than in nonsmokers; and that inhaled insoluble alpha-emitting particles represent a hazard five orders of magnitude greater than equivalent weights of chemical carcinogens. Gofman concludes that because of this lung cancer potential, people throughout the world should reject the production of nuclear fission energy which involves plutonium. 
In the second report, "Estimated Production of Human Lung Cancers by Plutonium from Worldwide Fallout, "Gofman uses the values for "lung cancer doses" developed in the first paper to estimate that plutonium fallout has committed 1 million persons* worldwide to plutonium-induced lung cancer and that the current annual death rate in the Northern Hemisphere due to plutonium-induced lung cancer is 10,000. Projecting these estimates to a developing nuclear power industry, he predicts that if only $0.01 \%$ of the plutonium used in power production enters the environment, there will be 500,000 additional deaths from plutonium-induced lung cancer each year, an increase of $25 \%$ in the annual lung cancer death rate.

Gofman's case is built primarily upon three premises, none of which is founded on experimental evidence:

1) the risk-per-unit-dose concept, which assumes 1 inearity of response over an extremely wide range extending to very low doses;

2) the concept that alpha irradiation from inhaled plutonium will increase the incidence of lung cancer by the same proportion that cancers of other tissues are increased by a variety of radiation exposures; and

3) that smokers as a group are at exceptionally high risk from inhaled plutonium because of long-term retention of plutonium particles in the tracheobronchial region of the lungs.

\section{The Risk-Per-Unit-Dose Concept}

In establishing his risk-per-unit-dose concept, Gofman makes use of his earlier conclusion (3) that, after a latent period of 10-15 years, radiation-induced lung cancer increases by $2 \% / r e m$ each year in an irradiated population over the spontaneous lung cancer death rate. This conflicts with the estimates made by the National Academy of Sciences Committee on Biological Effects of Ionizing Radiation (BEIR); after

* 116,000 persons in the USA. 
careful consideration of the available data and the literature, the BEIR Committee concluded the increase would be $0.2 \% / \mathrm{rem},(4, \mathrm{p} .171)$ with an average of $0.29 \%$ for bronchial cancer. (4,p.150) Gofman's figure, which is 10 times higher, is a matter of opinion only, unsupported by data.

Gofman compares his $2 \%$ figure with a value of $0.5 \%$ increase per rem, which he attributes to the BEIR report. In fact, this value was given by the BEIR Committee as a tentative prediction of an upper limit if enough more cancer deaths occur in the study populations; it is not what current data support. Gofman derived his estimate of risk-per-unit-dose from various published epidemiological data, concluding that if a certain amount of radiation is released into the environment a certain number of 1 ung cancers will be produced--regardless of the type of radiation, how the radiation is distributed over the population, or how it is delivered to individuals within the population. The report of the United Nations Scientific Committee on the Effects of Atomic Radiation (UNSCEAR) ${ }^{(5)}$ warns against this sort of misuse:

Estimates of risk per unit dose derived from epidemiological investigations are valid only for the doses at which they have been estimated and they can be applied to a range of doses only if there is a linear relationship between dose and incidence, since extrapolations beyond that range may lead to gross errors.

The UNSCEAR report is careful not to calculate risk estimates where the available data do not support a linear relationship. An example is the lung cancer data on the Hiroshima atomic bomb survivors, where the risk per rem decreases with increasing dose. The BEIR report ${ }^{(4)}$ discussed Gofman's estimate of the cancer risk from exposure to low level doses of radiation and concluded that Gofman overestimated the relative risk of radiation-induced solid tumors by a factor of 4-5 in 0-9 year-olds and by a factor of 10 in all others.

Because there is no empirical evidence on the carcinogenic effects of radiation in human beings at doses lower than 210 rem, the relationship between dose and cancer induction is unknown at such low doses. In the BEIR and UNSCEAR reports a linear relationship is assumed to insure 
conservatism, both in applying the derived risk estimates to radiation protection practices and in comparing biological risks of radiation and alternative options. Since neither the risk estimates of the BEIR report nor those of the UNSCEAR report are represented to be measures of the magnitude of the actual occurrence of radiation-induced cancer, it would not be prudent to use them for that purpose.

Finally, the National Council on Radiation Protection and Measurements ${ }^{(6)}$ continues to believe "that risk estimates for radiogenic cancers at low doses and low dose rates derived on the basis of linear (proportional) extrapolation from the rising portions of the dose-incidence curves at high doses and high dose rates...cannot be expected to provide realistic estimates of the actual risks from low-level, low-LET radiations, and have such a high probability of overestimating the actual risk as to be of only marginal value, if any, for purposes of realistic risk-benefit evaluation." Application of these risk estimates to high-LET radiations, such as alpha radiation from plutonium, could be just as tenuous. Furthermore, the risk estimates in the UNSCEAR and BEIR reports are derived from specific types of radiation exposure, none of which involved alpha radiation emitted from particles similar to plutonium deposited in the lungs. The Multiplier Effect of Alpha Radiation

The second Gofman premise, that radiation multiplies the effects of other carcinogenic influences, was considered by the International Commission on Radiological Protection ${ }^{(7)}$ and found to be unsupported by the scientific literature. According to Gofman's concept, a given radiation dose will increase the levels of a11 naturally-occurring cancers by the same percentage, regardless of the actual incidence of natural1y-occurring cancers in the population.

Gofman applies the value of $2 \% /$ rem of exposure increase over the spontaneous rate to al1 types of cancer. However, since the incidence rates of natural1y-occurring cancers vary, his estimates do not necessarily reflect accurately the differences in susceptibility of various 
tissues to radiation-induced cancer. Gofman's figure would lead to significant overestimation of excess cancers of tissues which have a relatively high spontaneous cancer rate (uterus, ovary, esophagus, larynx, skin, etc.) but which have not been found to actually develop excess cancers in irradiated populations. (7)

Gofman purports to base his risk estimates on the "spontaneous" cancer rate in humans. Since $90 \%$ of malignant neoplasms in human beings are thought to be due to environmental factors, ${ }^{(8)}$ Gofman's predictions are in fact based on the assumption that alpha radiation from plutonium deposited in lungs increases the incidence of all lung cancer, both natural and due to all inhaled environmental pollutants, by $2 \% / \mathrm{rem} /$ year. This assumes that part of the cancer risk from plutonium depends on the occurrence of cancers from other causes. Since there are no cancer incidence data for plutonium deposited in lungs of human beings, the validity of this assumption is not known. However, not all environmental pollutants act upon the same tissues within the lung. This is illustrated by the variety of tumor types that occurs among workers with differing occupational exposures and among smokers and nonsmokers.

Increased Cancer Risk to Smokers

The results of animal experiments indicate that inhalation of plutonium does not increase the incidence of cancer of the bronchial epithelium, the type of 1 ung cancer that occurs most frequently in both smoking and nonsmoking human beings and in most occupational exposures. Plutonium inhaled by experimental animals is deposited in the peripheral pulmonary regions of the lung. $(10)$ Therefore, it is these tissues which are irradiated, rather than the bronchial epithelium, and the predominant carcinogenic effect is cancer of the bronchiolar-alveolar epithelium. In human beings, however, bronchiolo-alveolar carcinoma is the least common of the major lung cancers, accounting for only $3-6 \%$ of the total $(11)$ in both smokers and nonsmokers. (12) Therefore, since it has not been proved that plutonium increases the incidence of naturally-occurring and environmental pollutant-induced types of lung cancer in man, the use of the 
relative risk approach may lead to erroneous conclusions. If Gofman insists on using the relative risk approach, the more appropriate base1 ine would be the incidence of the tumor type known to be caused by inhaled plutonium in animals (bronchiolo-alveolar carcinoma), which comprises only $3-6 \%$ of human lung cancers. This would result in a nearly 20-fold reduction in Gofman's risk estimate.

Gofman's major erroneous premise introduces a large error into his predictions. He concludes that the risk to cigarette smokers from plutonium-induced lung cancer is greater than for nonsmokers because in smokers clearance of plutonium particles from the large airways of the lungs (the tracheobronchial region) is impaired. On the basis of published observations of areas denuded of cilia in the bronchial epithelium of cigarette smokers' lungs, Gofman concludes that the clearance of plutonium particles would be impaired in $25 \%$ of the tracheobronchial region of the lungs of persons who smoke one package per day. Therefore, $25 \%$ of plutonium particles deposited in the tracheobronchial region and particles cleared to this region from the pulmonary region would be retained in the tracheobronchial region with a half-time of 500 days. Experimental evidence does not support this conclusion.

Cigarette smoke has been reported to inhibit ciliary activity of the respiratory tract. (13) However, Albert et al. (14) found that inhaled particles were actually cleared more rapidly in smoking males than in nonsmokers. Lourenco et a1. (15) observed abnormal accumulations of particles in the tracheobronchial region of the lungs of smokers several hours after inhalation of a test aerosol. There was a delay of about 2 hours before particle clearance began, but after 5 or 6 hours there was little, if any, difference in the amount of particles remaining in the lungs of the smokers and nonsmokers. There is no evidence to support Gofman's claim that clearance of plutonium particles from lungs of smokers would be impaired to the extent he suggests.

However, it is Gofman's estimate that plutonium particles are retained in the tracheobronchial region with a half-time of 500 days that leads to 
his astronomical predictions. Gofman correctly states that the half-time for clearance of plutonium from the nonciliated pulmonary region of the lungs is about 500 days. (16) This relatively long retention time in the pulmonary region appears to be due to the interaction of plutonium with the cellular constituents of this part of the lung where gas exchange occurs. The plutonium particles are engulfed by phagocytic cells and transported into intercellular spaces and lymphatic tissues, from which clearance is extremely slow. (10) However, there is no basis for his assumption of a 500-day half-time for retention of plutonium particles in the tracheobronchial region of the lungs of smokers. Such long-term retention of particles deposited in the large airways of the tracheobronchial region has not been demonstrated. Even if the ciliary clearance processes were impaired by cigarette smoking, the relatively frequent coughing experienced by most heavy smokers would tend to promote clearance of plutonium particles with other debris from the tracheobronchial region. Albert et a1. (14) observed that in both smokers and nonsmokers $90 \%$ of inhaled particles cleared from the tracheobronchial region within 13 hours. In most subjects, $90 \%$ clearance occurred within 6 hours. Lourenco et a1. (15) found that a mean of $46.8 \%$ of particles deposited in lungs of smokers was retained after 24 hours, compared with $48.3 \%$ in nonsmokers. Neither of these reports suggests anything approaching a retention half-time of 500 days for the tracheobronchial region. Although these studies were not with plutonium, there is no reason to expect the retention of plutonium to differ greatly from the test aerosols that were used. For example, plutonium is cleared from the tracheobronchial region of dog lungs with a half-time of 2-3 days. (17) The International Commission on Radiological Protection's Task Group on Lung Dynamics recommended a clearance halftime value of 0.1-0.2 days for plutonium dioxide in the tracheobronchial ragion. $(18,19,20)$ There is no evidence that this does not apply to smokers as well as to nonsmokers.

If plutonium were in fact retained in the tracheobronchial region of the lungs of smokers with a half-time of 500 days, then other inhaled 
particles also could be expected to have long retention times. This would make smokers especially vulnerable to choking to death when exposed to air containing moderately high concentrations of dust, a situation which is obviously contrary to experience.

Another consideration overlooked by Gofman is that alpha particles from plutonium penetrate only to about $40 \mu \mathrm{m}$. Plutonium particles cleared from bronchial areas by mucociliary action would probably be encased in mucus and/or macrophages of that thickness or greater. Thus, it is unlikely that a bare plutonium particle would come to rest on a bare unciliated area of the bronchial ephithelium. Since, as Gofman agrees, smokers have bronchial squamous metaplasia, the bronchial epithelium would be thicker and the sensitive intermitotic basal cells would be further protected from alpha particles. This argument indicates that smoking, with resulting increased mucus production and squamous metaplasia, might actually protect against the hazards of plutonium particles while they are present in the bronchi.

\section{OTHER ERRORS IN GOFMAN'S LOGIC}

Other errors of fact and logic in Gofman's reports are illustrated by the following:

1) Using a value of $2000 \mathrm{rem} / \mathrm{LC} i$ total alpha dose to lung from inhaled plutonium, Gofman hypothesizes that deposition of $10.5 \mathrm{pCi}$ fallout plutonium represents a potential dose of about $21 \mathrm{mrem}$. This is in agreement with the UNSCEAR value of $20 \mathrm{mrem}$, the total integrated dose to the pulmonary region of the lung over a 50-year period from fallout plutonium. This total lifetime dose from fallout plutonium is approximately equal to the dose the tracheobronchial and pulmonary regions of the lungs receive each year from breathing air containing only those radionuclides (such as radon and lead-210) which occur naturally in all air. Thus, at any time, the alpha radiation dose from inhaled fallout plutonium is much less than the dose 
to the respiratory tract from background alpha radiation. If Gofman were correct about plutonium, inhaled natural radon and lead-210 would have been responsible for much higher incidences of human lung cancer than have occurred throughout the history of man.

2) The reports lack reliable statistical content; for instance, Gofman uses averages rather than distributions, particularly when extremes are unknown. This can give fallacious results. For example, Gofman says that the incremental effect of ionizing irradiation is age-dependent, yet uses the $2 \%$ figure for the increased risk per rem uniformly, without consideration of age variations in the hypothetical population. The category "smoker" embodies a continuum, from several cigarettes per day to several packs per day, yet half the people are treated simply as smokers. To be statistically correct, an investigator looks at all the variables at a distributional level and applies the appropriate laws of distributional calculus to form conclusions.

3) If Gofman's premise that clearance of plutonium from lungs of sinokers is greatly impaired is true, human autopsy data should be showing much higher lung burdens of plutonium in smokers than in nonsmokers. This has not been revealed in the results published to date.

\section{CONCLUSIONS}

There is no sound basis, either in data from animal experiments or experience with human beings, for Gofman's assumption that the lung cancer risk posed by low dose, low dose-rate alpha radiation from inhaled plutonium is linearly related to cancer incidence in persons exposed to higher dose, higher dose-rate $x$ - and gamma radiation from mostly external sources. Likewise, experimental evidence does not support his assumption 
that alpha radiation from plutonium deposited in the lungs increases the incidence of all lung cancer, whether natural or caused by exposure to environmental pollutants.

However, Gofman's radical overestimation of plutonium-induced deaths is based primarily on his erroneous assumption that cigarette smoking significantly increases the cancer risk from inhaled plutonium, and there is no evidence that cigarette smoking causes plutonium particles to be retained in the tracheobronchial region of the lungs with a half-time of 500 days. Thus, Gofman's calculated high radiation doses to the tracheobronchial epithelium of the lungs of smokers are unsupported, and in fact contradicted, by experimental data. It follows then that his estimates of the lung cancer risk to smokers from inhaled plutonium are without merit.

\section{ACKNOWLEDGMENTS}

I was aided in the preparation of this review by comments and criticisms from J. E. Ballou, G. E. Dagle, E. S. Gilbert, J. E. Lund, W. L. Nicholson, A. R. 01 sen, J. F. Park, H. M. Parker, E. Perrin, C. L. Simpson, B. 0. Stuart, J. M. Thomas, and R. C. Thompson. I am indebted to L. Counts for editorial assistance. 


\section{REFERENCES}

1. Jack Anderson's Column, Washington Post, September 19, 1975.

2. Congressional Record-Senate, July 31, 1975, S14600-S14636.

3. J. W. Gofman and A. R. Tamplin, "Epidemiologic Studies of Carcinogenesis by Ionizing Radiation." In: Proceedings of the Sixth Berkeley Symposium on Mathematical Statistics and Probability, Statistical Laboratory, University of California, U.C. Press, Berkeley, CA, 1972.

4. The Effects of Populations of Exposure to Low Levels of Ionizing Radiation. Report of the Advisory Committee on the Biological Effects of Ionizing Radiations, National Academy of Sciences, National Research Counci1, Washington, DC, 1972.

5. Ionizing Radiation: Levels and Effects. Report of the United Nations Scientific Committee on the Effects of Atomic Radiation to the United Nation General Assembly, New York, 1972.

6. Review of the Current State of Radiation Protection Philosophy. NCRP Report No. 43, National Council on Radiation Protection and Measurements, Washington, DC, 1975.

7. Radiosensitivity and Spatial Distribution of Dose. Report Prepared by Two Task Groups of Committee 1 of the International Commission on Radiological Protection, ICRP Publication 14, Pergamon Press, Oxford, 1969.

8. B. Macmahon, "Epidemiologic Aspects of Carcinogenesis." In: Man's Health and the Environment - Some Research Needs, Report of the Task Force on Research Planning in Envirormental Health Science, National Institute of Health, U.S. Government Printing Office, Washington, DC, 1970.

9. J. W. Berg, "Epidemiology of the Different Histologic Types of Lung Cancer." In: Morphology of Experimental Respiratory Carcinogenesis, AEC Symposium Series 21, U.S. Atomic Energy Commission, Division of Technical Information, Springfield, VA, 1970.

10. W. J. Bair, J. E. Ballou, J. F. Park and C. L. Sanders, "Plutonium in Soft Tissues with Emphasis on the Respiratory Tract." In: Handbook of Experimental Pharmacology, Springer-Verlag, Berlin, $197 \overline{3}$.

11. S. D. Greenberg, M. N. Smith and H. J. Spjut, "Bronchiolo-Alveolar Carcinoma-Cell of Origin." Amer. J. of Comp. Path. 63:153-167, 1975. 
12. N. C. Delarue et al., "Bronchiolo-Alveolar Carcinoma." Cancer 29:90-97, 1972.

13. T. Dalhamn and R. Rylander, "Ciliastatic Action of Cigarette Smoke." Arch. Otolaryn. 81:379-382, 1965.

14. R. E. Albert et al., "Short-term Effects of Cirgarette Smoking on Bronchial Clearance in Humans." Arch. Environ. Health 30:361-367, 1975.

15. R. V. Lourenco, M. F. Klimek and C. J. Borowski, "Deposition and Clearance of $2 \mu$ Particles in the Tracheobronchial Tree of Normal Subjects - Smokers and Nonsmokers." J.Clinical Invest. 50:1411-1420, 1971 .

16. L. Watts, "Clearance Rates of Insoluble Plutonium-239 Compounds from the Lung." Health Phys. 29:53, 1975.

17. P. E. Morrow et al., "The Retention and Fate of Inhaled Plutonium Dioxide in Dogs." Health Phys. 13:113-133, 1967.

18. "Deposition and Retention Models for Internal Dosimetry of the Human Respiratory Tract." Report for the International Commission on Radiological Protection, by the Task Group on Lung Dynamics, Health Phys. 12:173-207, 1966.

19. P. E. Morrow, "Models for the Study of Particle Retention and Elimination in the Lung." In: Inhalation Carcinogenesis, AEC Symposium Series 18, U.S. Atomic Energy Commission, Division of Technical Information, Springfield, VA, 1970.

20. Inhalation Risks from Radioactive Contaminants. IAEA Technical Report Series No. 142, Report of a panel on inhaTation risks from radioactive contaminants, to the International Atomic Energy Agency, Vienna, 1973. 
BNWL-2067

DISTRIBUTION

\section{OFFSITE}

A. A. Churm

Chicago Patent Group

Energy Research and

Development Administration

9800 S. Cass Avenue

Argonne, IL 60439

N. F. Barr

Division of Biomedical and Environmental Research

Energy Research and Development Administration Washington, DC 20545

H. D. Bruner

Division of Biomedical and Environmental Research

Energy Research and Development Administration Washington, DC 20545

Dr. W. W. Burr

Division of Biomedical and Environmental Research Energy Research and Development Administration Washington, DC 20545

C. E. Carter

Division of Biomedical and Environmental Research

Energy Research and Development Administration Washington, DC 20545

Dr. J. A. Coleman

Office of Assistant Administrator for Environment and Safety

Energy Research and Development Administration Washington, DC 20545

G. P. Dix

Division of Biomedical and Environmental Research Energy Research and Development Administration Washington, DC 20545
T. J. Dobry

Nuclear Research and Application

Energy Research and Development Administration Washington DC 20545

C. W. Edington

Division of Biomedical and Environmental Research

Energy Research and Development Administration Washington, DC 20545

H. Hollister

Deputy Assistant Administrator for Environment and Safety Energy Research and Development Administration Washington, DC 20545

J. L. Liverman

Assistant Administrator for Environment and Safety Energy Research and Development Administration Washington, DC 20545

M. L. Minthorn

Division of Biomedical and Environmental Research Energy Research and Development Administration Washington, DC 20545

B. W. Wachholz

Division of Biomedical and Environmental Research Energy Research and Development Administration Washington, DC 20545

M. B. Biles

Division of Safety, Standards and Compliance

Energy Research and Development Administration Washington, DC 20545 
L. J. Deal

Division of Safety, Standards and Compliance

Energy Research and

Development Administration Washington, DC 20545

G. C. Facer

Division of Military Applications

Energy Research and

Development Administration

Washington, DC 20545

J. H. Harley

Health and Safety Laboratory

Energy Research and

Development Administration

376 Hudson Street

New York, NY 10014

Technical Information Center (27)

Energy Research and

Development Administration

R. Alexander

Nuclear Regulatory Commission

Washington, DC 20555

E. Alpen

University of California

Lawrence Berkeley Laboratory

Berkeley, CA 94720

Dr. Andrea Bianco

Lab Fisica Sanitaria

C.N.E.N. Centro di Calcolo

V. Mazzini, 2

40138 Bologna

Italia

J. A. Bonnel1

Central Electricity

Generating Board

Nuclear Heaith and Safety Dept.

Courtenav House, 18 Warwick Lane

London EC4P 4EB

Engl and
R. J. Budnitz

University of California Lawrence Berkeley Laboratory

Berkeley, CA 94720

Dr. Gordon C. Butler

Director

Division of Radiation Biology

National Research

Council of Canada

Ottawa 7

Ontario, Canada

G.-W. Casarett

University of Rochester

School of Medicine

and Dentistry

Rochester, NY 14620

B. L. Cohen

Department of Physics

University of Pittsburgh

Pittsburgh, PA 15260

Dr. G. F. Clemente

Comitato Nazionale per Engergia Nucleare

C.P. 2400. 00100 Roma

Italy

T. J. Connolly

Thermosciences Division

Stanford University

Stanford, CA 94305

Dr. H. T. Daw

International Atomic Energy Agency

Karntner Ring 11

P. 0. Box 590

A-1011

Vienna, Austria

G. W. Dolphin

National Radiological

Protection Board

Building 566

Harwe11, Didcot

Oxfordshire 0X11 ORQ

England 
OFFSITE

P. W. Durbin

University of California

Lawrence Berkeley Laboratory

Berkeley, CA 94720

\author{
R. D. Evans \\ 4621 East Crystal Lane \\ Scottsdale, AR 85253 \\ Dr. L. E. Feinendegen \\ Director of \\ Institute of Medicine U.F.A. \\ Institute fur Medizin \\ Kernforschungsanlage Julich \\ Postfach 365 \\ 517 Julich \\ West Germany \\ J. W. Gofman \\ Comm. for Nuclear Responsibility \\ P.0. Box 2329 \\ Dublin, CA 94566
}

M. I. Goldman

Radiobiology Laboratory

University of California

at Davis

Davis, CA 95616

D. Grahn

Argonne National Laboratory

9700 South Cass Avenue

Argonne, IL 60439

J. W. Healy

Los Alamos Scientific Laboratory

Los Alamos, NM 87544

Dr. Wolfgang Jacobi

Gesell schaft

Fur Strahlen-und Umweltforschung

Institute fur Strahlenschutz

Ingolstadter LandstraBe 1

Post Oberschleibheim

8042 Neuherberg

West Germany
J. Lafuma

6 Ave Clemenceau

92330 Sceaux

France

C. C. Lushbaugh

0ak Ridge Associated Universities P.0. Box 117

Oak Ridge, TN 37830

Or. A. M. Marko

Chalk River Nuclear Laboratories

Chalk River, Ontario

Dr. Osamu Matsuoka

Chief, Internal Expolsure Lab

Division of Radiation Hazards

National Institute of Radiological Sciences

9-1, 4-chome

Anagawa

Chiba-shi

Japan

C. W. Mays

Radiobiology Division

University of Utah

Salt Lake City, UT 84132

R. 0. McClellan

Lovelace Foundation

Inhalation Toxicology Research

Institute

5200 Gibson Blvd., S.E.

Albuquerque, NM 87108

R. H. Mole

Director, Medical Research Council

Radiobiological Research Unit

Harwel1, Didcot, Berkshire

England

C. C. Palmiter

Office of Radiation Programs

Environmental Protection Agency

4th \& Main Streets, S.W.

Washington, D.C. 20460 


\section{OFFSITE}

D. J. Rose

Massachusetts Institute of Technology

Room 24-207

Cambridge, MA 02139

R. E. Rowl and,

Argonne National Laboratory

9700 Cass Avenue

Argonne, IL 60439

Dr. Leonard A. Sagan

Department of

Environmental Medicine

Palo Alto Medical Clinic

300 Homer Avenue

Palo Alto, CA 94301

G. B. Schofield

British Nuclear Fuels Limited

Windscale and Calder Works

Sellafields, Calderbridge, Cumbria

England

Prof. Giovanni Silini

Director

Laboratorio di Radiobiologia Animale

Centro di Studi Nucleari

Della Casaccina

Comitato Nazionale per

L'Energia Nucleare

Casella Postale N. 2400

Rome, Italy

M. B. Snipes

Lovelace Foundation Inhalation

Toxicology Research Institute

5200 Gibson Blvd., S.E.

Albuquerque, NM 87108

Dr. Walter Snyder

Assistant Director

Health Physics Division

Oak Ridge National Laboratory

Post Office Box $X$

Oak Ridge, TN 37830
J. N. Starinard

10 Fal1 Acres Dr.

Pittsford, NY 14534

W. R. Stratton

Los Alamos Scientific Laboratory P.0. Box 1663

Los Alamos, NM 87544

L. S. Taylor

National Council on Radiation

Protection and Measurements

7910 Woodmont Avenue

Suite 1016

Washington, DC 20014

R. G. Thomas

Los Alamos Scientific Laboratory

P.0. Box 1663

Los Alamos, NM 87544

Dr. Arthur C. Upton

Nuclear Medical Division

Brookhaven National Laboratory

Upton, L.I., NY 11973

A. M. Weinberg

Institute for Energy Analysis

Oak Ridge Associated Universities

P.0. Box 117

Oak Ridge, TN 37830

L. R. Wallis

General Electric Company

175 Curtner Avenue

San Jose, CA 95125

Research and Technical

Support Division

Oak Ridge Operations

Energy Research and

Development Administration

Oak Ridge, TN 37830 
ONSITE

Environmental and Laboratory

Programs Division

Richland Operations Office

Energy Research and

Development Administration

Hanford Engineering

Development Laboratory

E.A. Evans

J. F. Leitz

Battelle-Northwest

W. J. Bair (10)

J. E. Ballou

N. E. Carter

D. B. Cearlock

L. C. Counts

G. E. Dagle

J. W. Finnigan

J. C. Fox

E. S. Gilbert

A. J. Haverfield

H. V. Larson

J. E. Lund

W. L. Nichol son

J. M. Nielsen

A. R. 01 sen

J. F. Park

H. M. Parker

E. Perrin

C. L. Sanders

C. L. Simpson

B. 0. Stuart

J. M. Thomas

R. C. Thompson

C. M. Unruh

B. E. Vaughan

W. R. Wiley

Technical Information (3)

Technical Publications 